\title{
Teaching NeuroImage: Traumatic Dissection of Lenticulostriate Arteries Within an
}

\section{Enlarged Perivascular Space}

\author{
Author(s): \\ Paul JANVIER ${ }^{1}$; Basile KERLEROUX, MD-MSc ${ }^{1}$; David Varlan, MD $^{2}$; Christine Rodriguez-Régent, \\ $\mathrm{MD}^{1}$; Denis Trystram, MD ${ }^{1}$; Julien Allard ${ }^{1}$; Maxime Drai ${ }^{1}$; Catherine Oppenheim, MD-PhD ${ }^{1}$; Wagih \\ Ben Hassen, MD-MSc ${ }^{1}$; Olivier Naggara, MD-PhD ${ }^{1}$
}

Neurology® Published Ahead of Print articles have been peer reviewed and accepted for publication. This manuscript will be published in its final form after copyediting, page composition, and review of proofs. Errors that could affect the content may be corrected during these processes. 


\section{Corresponding Author:}

Paul JANVIER

paul_janvier@live.fr

Affiliation Information for All Authors: 1. Neuroradiology Department, GHU Paris Psychiatrie et Neurosciences, site Sainte-Anne, Paris, France; 2. Neurology Department, Delafontaine Saint Denis Hospital, Saint Denis, France

\section{Contributions:}

Paul JANVIER: Drafting/revision of the manuscript for content, including medical writing for content; Major role in the acquisition of data; Study concept or design; Analysis or interpretation of data; Additional contributions: execution/organization of the case Report. Execution of arteriography.

Basile KERLEROUX: Drafting/revision of the manuscript for content, including medical writing for content; Study concept or design

David Varlan: Major role in the acquisition of data; Additional contributions: Neurological examination Christine Rodriguez-Régent: Analysis or interpretation of data; Additional contributions: manuscript review and critique

Denis Trystram: Analysis or interpretation of data; Additional contributions: manuscript review and critique

Julien Allard: Major role in the acquisition of data

Maxime Drai: Major role in the acquisition of data

Catherine Oppenheim: Major role in the acquisition of data

Wagih Ben Hassen: Analysis or interpretation of data; Additional contributions: manuscript review and critique

Olivier Naggara: Analysis or interpretation of data; Additional contributions: manuscript review and critique

Number of characters in title: 12

Abstract Word count: 109 
Word count of main text: 109

References: 2

Figures: 2

Tables: 0

Neuroimage Legend Count: $35+26$

Supplemental: 1_Patient_consent-to-disclose-form 2_Teaching_slides3_Manuscript_With

Tracked_Changes 4_Cover_Letter_R1

Search Terms: [ 6 ] Infarction, [ 7 ] Intracerebral hemorrhage, [ 120 ] MRI, [ 264 ] Brain trauma

Study Funding: The authors report no targeted funding

Disclosures: The authors report no disclosures relevant to the manuscript.

\section{CASE}

A 33-year-old woman was admitted with right side hemiplegia after head trauma.

Brain $\mathrm{MRI}$ revealed an acute ischemic stroke in the left lenticulostriate territory and a parenchymal hematoma (Figure 1). The hematoma occurred within an enlarged perivascular space (PVS) which had been incidentally discovered ten years prior. It was suspected that a traumatic dissection of lenticulostriate arteries within the PVS was responsible for both ischemic and hemorrhagic events (Figure 1). Healing of the hematoma and disappearance of the PVS and the lenticulostriate arteries were observed 2 months later (Figure 2). Excessive mobility of lenticulostriate arteries 
within an enlarged PVS may explain the mechanism of traumatic dissection in this case.

\section{LEGEND}

Figure 1: $M R I$ images acquired 10 years before the head injury $(A, B)$ and at the time of admission (C, D) immediately following head trauma.

Time-of-flight (TOF) imaging showed an enlarged perivascular space (PVS) centered by lenticulostriate arteries (arrow, A). Imaging after the trauma revealed bleeding within the PVS on T2 FLAIR (C) and ischemia of the caudate nucleus (D).
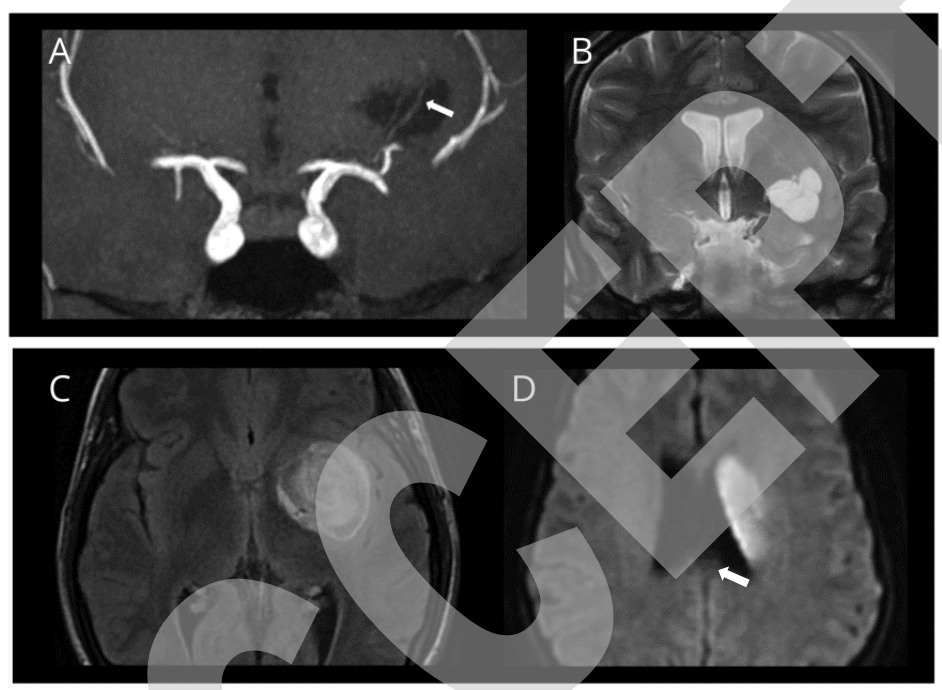
Figure 2: MRI images and catheter angiogram performed two months following hospital admission.

On 2 months angiography (A), lenticulostriate arteries were no longer visible (arrows, A, B). Shrinkage of both PVS and hematoma were observed on TOF and T2 (B, C).

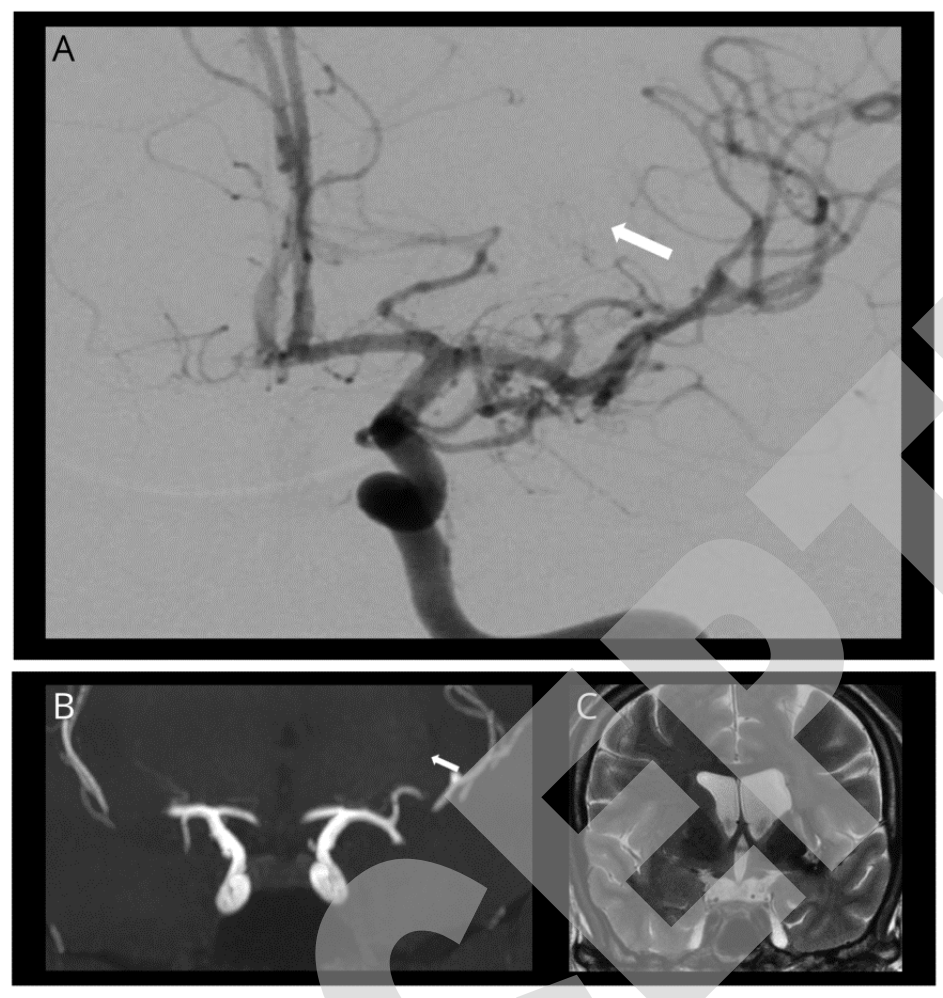

Teaching Slides-http://links.Iww.com/WNL/B698

\section{REFERENCES}

1. Kwee RM, Kwee TC. Virchow-Robin spaces at MR imaging. Radiogr Rev Publ Radiol Soc N Am Inc. 2007;27:1071-1086.

2. Salzman KL, Osborn AG, House P, et al. Giant Tumefactive Perivascular

Spaces. Am J Neuroradiol. American Journal of Neuroradiology; 2005;26:298-305. 


\section{Neurology}

\section{Teaching NeuroImage: Traumatic Dissection of Lenticulostriate Arteries Within an Enlarged Perivascular Space}

Paul JANVIER, Basile KERLEROUX, David Varlan, et al.

Neurology published online December 8, 2021

DOI 10.1212/WNL.0000000000013185

\section{This information is current as of December 8, 2021}

Updated Information \&

Services

Subspecialty Collections

Permissions \& Licensing

Reprints including high resolution figures, can be found at:

http://n.neurology.org/content/early/2021/12/07/WNL.0000000000013185. citation.full

This article, along with others on similar topics, appears in the following collection(s):

\section{Brain trauma}

http://n.neurology.org/cgi/collection/brain_trauma

Infarction

http://n.neurology.org/cgi/collection/infarction

Intracerebral hemorrhage

http://n.neurology.org/cgi/collection/intracerebral_hemorrhage

MRI

http://n.neurology.org/cgi/collection/mri

Information about reproducing this article in parts (figures,tables) or in its entirety can be found online at:

http://www.neurology.org/about/about_the_journal\#permissions

Information about ordering reprints can be found online:

http://n.neurology.org/subscribers/advertise

Neurology ${ }^{\circledR}$ is the official journal of the American Academy of Neurology. Published continuously since 1951, it is now a weekly with 48 issues per year. Copyright (C) 2021 American Academy of Neurology. All rights reserved. Print ISSN: 0028-3878. Online ISSN: 1526-632X.

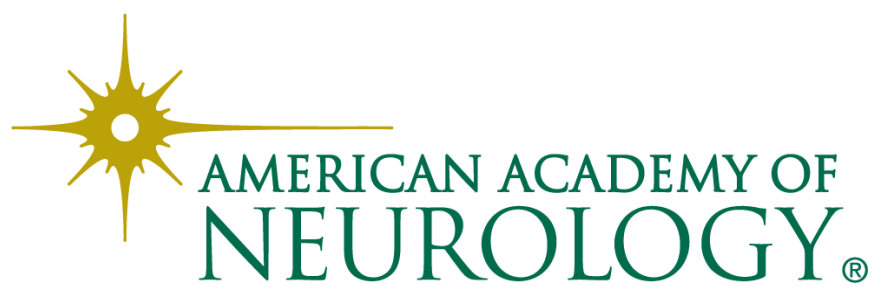

